\title{
Volunteering as a Way of Taking Responsibility for the Sustainability of Social Economy Enterprises
}

\author{
By Ion Tudor ${ }^{1}$, Daniela Ileana Predețeanu ${ }^{1}$, Cătălina Picu ${ }^{1}$, Cristina State ${ }^{1}$
}

\begin{abstract}
Our study is about the perception of people towards volunteering, in order to propose solutions to improve the management for the sustainability of social economy enterprises. The question we want to answer in our paper is about the availability for participation in voluntary activities to ensure the sustainability of social economy enterprise. This question became the main objective of our study. To answer this question we conducted a survey based on a questionnaire in a micro-community from the Centre Region of Romania. Combining the quantitative and qualitative methods, thus ensuring the in-depth interpretation of the study results, the work hypotheses were tested with the IBM Statistics and AtlasTi applications. The results of our study confirm that the subjects surveyed are willing to take the responsibility of engaging in volunteering for the benefit of individuals or the community, thereby contributing to the creation of tangible economic and social values for the community. Finally we conclude that involving individuals in volunteering activities can be an valuable piece of information for the managers of social enterprises when it comes to taking the adequate strategic decisions, so as to obtain a competitive advantage that can be materialized in the utility of the work, the personal satisfaction as a result of work done, the integration into community etc.
\end{abstract}

Keywords: improving management, communities, social economy enterprise, solidarity, volunteering

\section{Introduction}

The much invoked paradigm of the welfare state is more and more often confronted with the reality of the economic, social and moral crises (Castles, 2002; Taylor-Goby, 2005;) (amplified most of the time at local, urban or rural community level) generating specific issues, of which we mention those related to: health, education, pollution and, overlapping with them all, the ageing population (Hemerijck, 2012; Klein, 2003; Rothstein, 2001).

By definition, the social economy is associated with private voluntary and solidary initiative, having a high degree of autonomy and responsibility (Harrison et all, 2009; Moulaert et Ailenei, 2005; Neamtan, 2009). Social economy enterprises (SEE), as representative entities of this economic sector (European Commission, 2013; Popescu et all, 2016), which were created with the specific purpose to serve their members and / or the community (Borzaga et Bodini, 2014; Phills et all, 2008; Brothers et Sherman, 2011; David et Sutton, 2011), assume the responsibility of solving economic and / or social problems to ensure the sustainability of local communities (Lewis et Swinney, 2007; Yunus et all, 2010; Magzan, 2014; Restakis, 2006). Achieving this goal may be possible to the extent to which companies manage their resources efficiently, since it is well known that social values cannot be generated unless economic values are also created to support 
them (Wood et Leighton, 2010; Franz et all, 2010). A performance criterion of social economy enterprises is the creation of social values (Franz et all, 2010; Petrella, 2014, Bugg-Levine et all, 2012; Harding, 2004), which can only be recognised if the business strategy defines the categories of beneficiaries (Choi et Majumdar, 2015; Epstein et McFarlan, 2011), and how these beneficiaries are served (Brown, 2017; Volkmann et all, 2012; Tibando, 2017; Rey-Garcia et all, 2017).

Man, as nucleus of the cell we call the economic and social life of the community (Allen, 2016; Ramadan et Borgonovi, 2015), is more and more often faced with a new paradigm, that of the individual-collective, where the community proves to be more than the total sum of its individuals (a fact clearly proven by daily events) (Nakano, 2000; Sablonniere et all, 2013). Within this new context of their existence, human beings are sometimes, simultaneously, the generators and the beneficiaries of the values created by the solidarity between individuals, inside the community where they live permanently or temporarily (Laskowski et Loidl, 2012; Bell et all, 2010). Solidarity, seen as the sum of the individual's abilities to be useful and good at the same time (Hancock, 2012), refers to the community as a whole and, "in extenso", to the human society. Solidarity is the essential element of all human activities (London et all, 2015) that ensure the continuity by training the future generations (Christie et Honig, 2006) which are capable of leading to progress in terms of the socio-economic development (Pantea, 2015). The availability to be solidary is an individual and a personal option, mainly manifested through participation in volunteer activities as a part a of the non-formal education and global citizenship (Barkin et Lemus, 2014; Moreanu et Mertens, 2013). The ability to manage volunteers in the social economy enterprise, whose peculiarity is that it uses the hired personnel and volunteer work (Table no. 1) for achieving its goals, is one of the manager's (managerial team's) challenges (Battilana et Lee, 2014).

Table no. 1: Peculiarities of enterprises by the criterion of capital ownership/equity

Public sector enterprises

- Are set up with majority/entirely state-owned capital;

- Are owned and managed by the state, through its representative bodies;

- Are created in the strategic branches of the economy;

- Generate profits;

- May receive subsidies to cover budget deficits;

- Conduct economic activities of public utility;

- The Board of Directors is appointed depending on political criteria, by the central or local administration bodies to which they are subordinated;

- Their development strategies are determined by the political party in power;

- The managerial decision bears the imprint of the governing political party.

Social economy enterprises (SEE)

- Are set up with private assets/equity;

- Are owned by the members;

- Are constituted to serve their members and the community;

- Generate financial surplus, which is shared in order to achieve the social goals;

- Are beneficiaries of donations and sponsorship;

- Participatory Management; involves the members and the community to achieve the set objectives; 


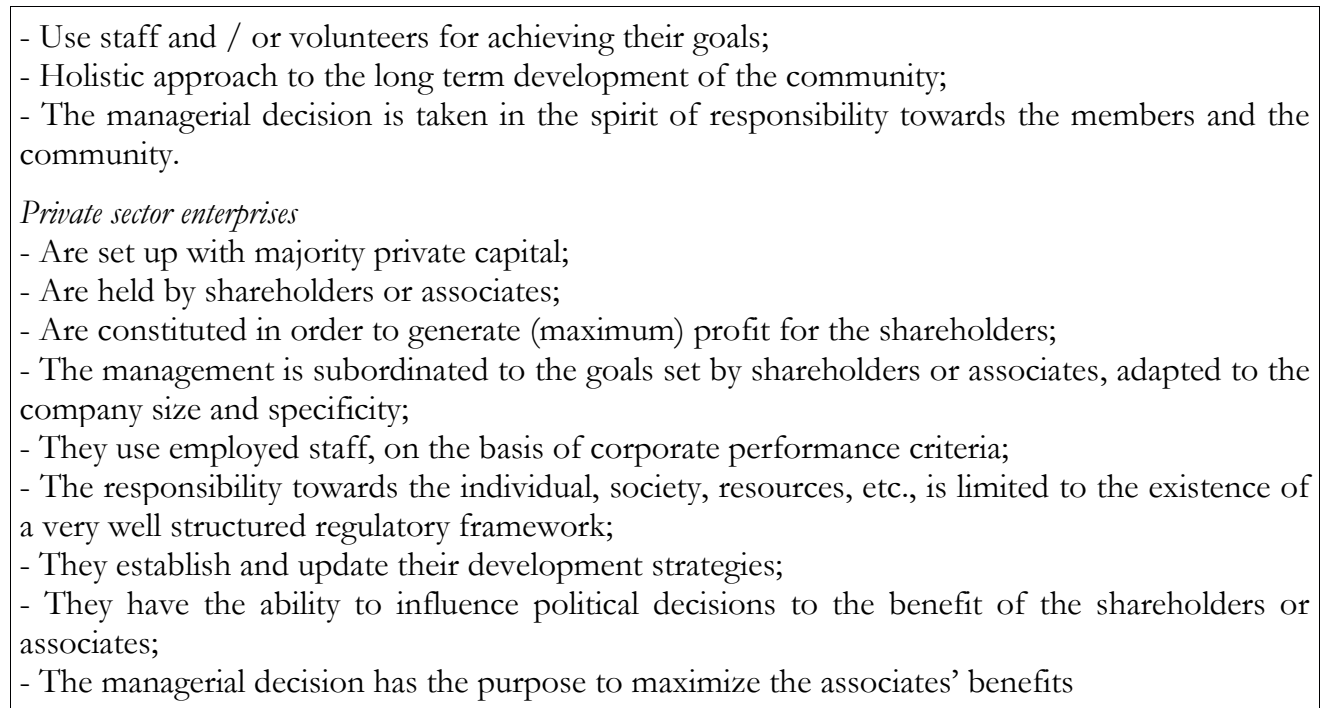
Source: Summary made by the authors, following documentary research

The peculiarities of social economy enterprises (collective interest-private interest, economic activities -non-profit activities, employed staff-volunteers, etc.) forces the managers of these entities to appeal to particular, hybrid and sometimes paradoxical action instruments (Plerhoples, 2015; Schmid, 2006; Ball, 2016). These businesses acting in a free market, open to all economic actors - become sources of social innovation and management, which aim to find a balance between solidarity and efficiency in an environment where the competition is more and more fierce (Tihon et Ingham, 2011; Bennis, 1969), the development must become sustainable and the growth is questioned (Tihon et Ingham, 2011).

As Warren Bennis outlined in the paper "Post-bureaucratic leadership" (Bennis, 1969) written since 1969 „modern organizations will have to respond to the increasing needs for "freedom" and for expressing the imagination, fantasy and pleasure to work. Therefore, the organizations will be, primarily, temporary systems capable to adapt and to constantly change, depending on the evolution of the environment and of individual needs. Secondly, they will be created around the problems to be solved", and social economy enterprises are no exception to these requirements.

\section{Literature Review}

A healthy dynamic of the relationships among individuals begins with the act of giving (offering), just like in a universal law of the mirror, to which we offer our image so that our true representation would be revealed to us (Kenneth, 2005).

Apparently invisible, solidarity, manifested through simple facts related to education, health, civic activity etc., accompanies the human being throughout life. The act of solidarity involves the intersection of four elements: desire for accomplishing solidary acts, motivational determination, material possibilities, existence of the beneficiary [50: 10].

In his classic work "Social division of labour", Emile Durkheim distinguishes two types of solidarity: mechanical and organic (Durkheim, 2014). Mechanical solidarity is 
attributed to the simple, archaic society, while organic solidarity is present in the modern society where the degree of differentiation and individualisation is much higher [51: 80]. Generally, quality-of-life in a society can be measured by how long and happy its inhabitants live [52: 105]. It is the context in which one of the consequences of solidarity is the improvement of the quality of life for people who, at some point, are in critical situations. The social economy sector, governed by principles that give priority to the individual and social objectives, is based on the principle of solidarity and collective responsibility [53: 2-3].

The availability to involve in voluntary activities is in itself an act of solidarity, according to the definition of volunteering: "....an activity for the benefit of others or of society, without seeking a material gain” (European Commission, 2010). The use of volunteers in social economy enterprises is an option that managers resort to more and more, and through their activities, the volunteers are doing true acts of human solidarity. Thus, according to Lund, there are, for example, cooperatives where the management activities are carried out by the members on a rotating basis, not for profit, not for charity, but for service [55:3]. In his work "Values and the sociology of values", Voicu enumerates the common European values, stipulated in the draft of the European Constitution, which enshrines the fact that these values are common to the Member States in a society characterised by pluralism, non-discrimination, tolerance, justice, solidarity and equality between men and women [56: 30-31].

According to Nogueira-Martins, solidarity, along with personal satisfaction and conflict resolution, is one of the motivations that lead individuals to engage in voluntary activities [57: 1].

An interesting approach to human solidarity is proposed by Frankl, the founder of logotherapy who, in his book "Man's search for meaning" (Frankl, 2006), signals that unemployed young people are often exposed to what the author calls unemployment neurosis, due to a double incorrect identification: being unemployed is equivalent to being useless and being useless is equivalent to a meaningless life; whenever these young people were persuaded to get involved as volunteers in youth organizations, in adult education, in public library services etc., thus managing to fill the excess of free time with meaningful activities, their health improved noticeably [58: 92].

The social importance of volunteering is underlined by the existence of a specific regulatory framework for NGOs, which are also social economy enterprises [59: 3, 60: 13-17]. Under this law, voluntary activities are carried out under the supervision of a volunteer coordinator who can be, in turn, a volunteer or an employee of the host organization [59: 13], who fulfils specific tasks related to the coordination and management of volunteers [60:13-17]. So the law outlines the premises for introducing a new occupation in the Romanian nomenclature of occupations: Manager of volunteers.

Responsibility is a mandatory condition of the involvement of individuals in volunteering for the sustainability of local communities. It represents man's conscious attitude, sense of responsibility towards the obligations he has assumed. Responsibility as a social phenomenon accompanies freedom, expressing the individual act of engagement in social interaction. According to Baltag \& Moraru, if we understand "responsibility as accountability for the results of man's social action, we acknowledge, on the one hand, that social action is the direct manifestation of responsibility, and, on the other hand, that freedom is a fundamental condition 
of responsibility" [61: 1].

\section{Objectives, Hypotheses and Work Methodology}

The specialized papers on the social economy sector - also known as the third sector or as solidarity economy [8: 2042,62,63,64,65] - unanimously agree with the idea that one of the characteristics of social economy enterprises is the use of both paid and volunteer work, as an expression of human and social solidarity and in order to achieve its purpose in the community in which it operates (Laville et Nyssens, 2004).

Starting from this premise, the main objective of our work is to investigate the members of a stable micro-community, which we have been observing since 2002, about their willingness to engage in volunteering.

The micro-community is defined by the Merriam-Webster dictionary as a community which occupies a micro-habitat (Merriam-Webster, 2017). According to McCold și Wachtel, "Micro-communities are the social networks that we all belong to that are fluid and dynamic, and include home, work, leisure, religious and other social sub-structures that bind us to society" (McCold et Wachtel, 1997). Hope [69: 389] uses the term "microcommunity" to designate the small groups of participants in an event organised for socialising. In the authors' opinion, using this term allows them to focus simultaneously on the social network and on physical interaction.

From the perspective of our study, the micro-community is a group of people who live in a relatively small space, who share common values and interests, characterised by mutual help, close social, economic and affective bonds among the members and a strong feeling of belonging.

The micro-community we have focused on in order to carry out the research took shape and developed as a socio-economic entity in less than 20 years. We were attracted by the way in which the relationships among the community members evolved. The exploratory analysis was carried out at micro level, because this offered the advantage of using a small social unit as a means of investigating the specific issues regarding social economy which could be encountered in various zones of Romania. We have thus created the conditions for exploring in detail certain similar issues that are characteristic of micro-communities [70: 29]. At the same time, we counted on the fact that carrying out the study in a microcommunity including people with whom we had interacted throughout time would contribute to eliminating much faster the barriers which appear at different stages of the study, the dialogue with the subjects becoming thus more fluid.

Thus, we continue the study initiated within the same micro-community in August 2015 on the awareness regarding social economy, in which we pointed out that the social economy sector (including social economy enterprises, as representative organizations) was little known at that date. The motivation to continue the research is justified by the fact that, although the surveyed subjects did not have a lot of information about social economy, at the time of the survey they knew a number of representative organizations in this sector, without being aware that these were social economy enterprises.

An additional motivation is that at the time of the survey, more than $80 \%$ of the microcommunity members (subjects participating in the study) had a history regarding their engagement in volunteering, which amplified our curiosity and resulted in defining the 
secondary objectives of the work, as follows:

1. What is the context in which the respondents have conducted volunteering;

2. Which are the conditions for the respondents to became involved in volunteering;

3. What are the consequences (outcomes) of the involvement of the surveyed subjects in volunteering.

The survey was conducted using a questionnaire administered directly, which contains a combination of questions with predefined answers and, for a nuanced interpretation, open questions, to which the subjects surveyed were asked to answer according to their own experience:

1. Have you ever participated in volunteering? With "yes", "no" answers.

2. How much time have you allocated to volunteering?

3. What is the greatest satisfaction that volunteering has given you?

4. Have you ever been the beneficiary of volunteering? With "yes", "no", "do not know" answers.

5. Currently, would you be willing to do voluntary work? With "yes", "no", "N. $A$ " answers.

6. Can you justify your response to the previous question?

7. Can you tell us the most beautiful story of the achievements obtained through your work?

To achieve the main objective of the paper, related to the availability of the surveyed subjects to involve in volunteering, we formulated the following work bypotheses:

Question: Have you ever participated in volunteering? With "yes", "no" answers.

The null bypothesis (HO): both variants of the answer are equally preferred by the respondents.

Alternative bypothesis (H1): one variant of the answer is preferred by the subjects participating in the study.

Referring to the availability of getting involved in voluntary activities in the future.

Question: Currently, would you be willing to do voluntary work? With "yes", "no", "N.A." answers.

The null bypothesis (HO): all variants of the answer are equally preferred by the surveyed subjects.

Alternative bypothesis (H1): one variant of the answer is preferred by the subjects participating in the study [71: 192; 72: 305-348; 73: 240-243; 74: 171-174].

Testing the work hypotheses formulated as part of the quantitative component of the research was carried out by studying the frequency of the responses (Affirmative / Negative / D.K.).

The secondary objectives of the paper refer to the context, conditions and consequences (outcomes) of the respondents' involvement in volunteering and were addressed by developing a working algorithm (Figure no. 1) that we applied for the interpretation of the answers to the open questions [75: 83]. The algorithm is based on the coding paradigm that facilitates the discovery of the:

- Causal conditions which determine the surveyed subjects to take on responsibilities by involving in voluntary activities in their community,

- the phenomenon - the responsible participation of the investigated subjects in solving the problems of local communities, by carrying out voluntary activities,

- The context in which the surveyed subjects were involved in volunteering,

- The conditions expressed by the surveyed subjects regarding their involvement in volunteering, 
- Action / interaction strategies adopted by the respondents to solve the specific problems in their community,

- Consequences / results obtained through volunteering: benefits for the community, benefits for the individual, benefits for the volunteer.

For the in-depth study of the researched phenomenon - the availability of the surveyed subjects to get involved in volunteering - we used a methodology which involves a combination between quantitative and qualitative working techniques [76: 122-126].

The qualitative component of the research was carried out in two ways: (1) analysis of the responses provided by the surveyed subjects to the open questions in the questionnaire and (2) observation of the behaviours and attitudes of the subjects, backed up by informal dialogue, both being enabled by our participation in the daily activities of the microcommunity. The field notes and the audio and video recordings allowed us to highlight some relevant aspects concerning the context in which the respondents were willing to involve in volunteering for the benefit of their communities.

The qualitative method of analysis compensated the need to supplement the quantitative research by detailing and nuancing the information on the studied micro-community and, finally, by shaping a picture which faithfully and dynamically reflects the reality regarding the availability of the surveyed subjects to get involved in volunteering, as well as by quantifying the effects of such an activity.

Processing of the qualitative data was achieved by: theoretical coding, qualitative content analysis, sequence analysis and visual presentation of data [77: 339-380].

The theoretical coding was conducted using the open coding technique which consisted in segmenting the material, attaching codes and building thematic code categories or families. For the qualitative content analysis we used mainly structural analysis which followed types of structures formed in the material and, overall analysis that allowed us to obtain a perspective on the context, conditions and consequences (outcomes) of the respondents' involvement in volunteering.

The results of the qualitative research are summarized from a positivist perspective, following the logical structure of the algorithm developed, through structured summaries, synopses, diagrams, matrices and they present the attitude of the surveyed subjects, their motivation, action strategies and results obtained by involving in volunteering.

The variables under investigation are presented in Table no. 2.

\section{Table no. 2: Variable Information}

\begin{tabular}{|c|c|c|c|c|}
\hline Variable & Position & Label & Measurement Level & Role \\
Gender & 1 & Gender & Ordinal & Input \\
Age & 2 & Age & Ordinal & Input \\
Occupation & 3 & Occupation & Ordinal & Input \\
Voluntary & 4 & Voluntary & Nominal & Input \\
Time_V & 5 & VTime & Scalar & Input \\
Beneficiary_V & 6 & VBeneficiary & Nominal & Input \\
Availability_V & 7 & VAvailability & Nominal & Input \\
Motivation_V & 8 & VMotivation & Nominal & Input \\
Achievement_V & 9 & VAchievement & &
\end{tabular}

Variables in the working file.

Source: data entry collected by the authors through the questionnaire 


\section{CAUSAL CONDITIONS}

The need to ensure (mainly social) products or services

not covered by the other economic sectors

CONTEXT OF VOLUNTEERS' INVOLVEMENT

Manifestation of the solidarity feeling

(CODE 02)

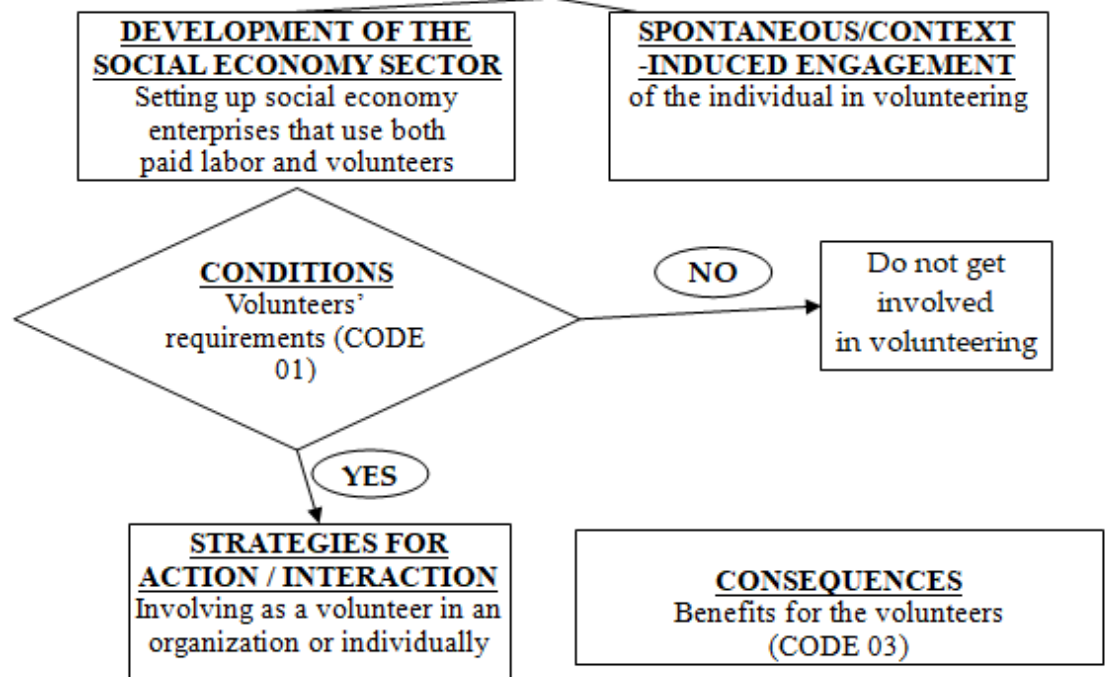

Figure no. 1: Research algorithm

Source: Designing the research by the authors

\section{Results. Discussions}

The researched micro-community consisted of 50 persons from which answered 30 adult subjects - 10 men (minimum score, 1) and 20 women (maximum score, 2) - aged between 18 (minimum score, 7) and 75 years (maximum score, 9); a significant proportion of the participants in the study is represented by people over 40 (mode, 9). Half of the subjects are employees (mode, 1), a much smaller percentage (6 subjects) being represented by entrepreneurs (Table no. 3).

Table no. 3: Statistics

\begin{tabular}{|l|l|c|c|c|}
\hline & Gender & Age & Occupation \\
\hline \multirow{2}{*}{$\mathrm{N}$} & Valid & 30 & 30 & 30 \\
\cline { 2 - 5 } & Missing & 0 & 0 & 0 \\
\hline Mode & 2 & 9 & 1 \\
\hline Minimum & 1 & 7 & 1 \\
\hline Maximum & 2 & 9 & 6 \\
\hline
\end{tabular}




\begin{tabular}{|c|c|c|c|c|c|}
\hline \multicolumn{2}{|c|}{ Gender } & Frequency & Percent & Valid Percent & Cumulative Percent \\
\hline \multirow{3}{*}{ Valid } & Male & 10 & 33.3 & 33.3 & 33.3 \\
\hline & Female & 20 & 66.7 & 66.7 & 100.0 \\
\hline & Total & 30 & 100.0 & 100.0 & \\
\hline \multicolumn{2}{|l|}{ Age } & Frequency & Percent & Valid Percent & Cumulative Percent \\
\hline \multirow{4}{*}{ Valid } & $<=25$ years old & 3 & 10.0 & 10.0 & 10.0 \\
\hline & $26-40$ years old & 8 & 26.7 & 26.7 & 36.7 \\
\hline & $>40$ years old & 19 & 63.3 & 63.3 & 100.0 \\
\hline & Total & 30 & 100.0 & 100.0 & \\
\hline \multicolumn{2}{|c|}{ Occupation } & Frequency & Percent & Valid Percent & Cumulative Percent \\
\hline \multirow{7}{*}{ Valid } & Employee & 15 & 50.0 & 50.0 & 50.0 \\
\hline & Entrepreneur & 6 & 20.0 & 20.0 & 70.0 \\
\hline & Retired & 5 & 16.7 & 16.7 & 86.7 \\
\hline & Unemployed & 1 & 3.3 & 3.3 & 90.0 \\
\hline & Pupil / student & 2 & 6.7 & 6.7 & 96.7 \\
\hline & No answer & 1 & 3.3 & 3.3 & 100.0 \\
\hline & Total & 30 & 100.0 & 100.0 & \\
\hline
\end{tabular}

Source: data processing, by the authors, in SPSS

Testing the main bypothesis regarding the availability of the subjects surveyed to do volunteering, was done starting from the frequency analysis of the responses provided by the subjects to the following questions (concerning both the past and their intention to continue these activities in a predictable time horizon):

1. „Have you everparticipated in volunteering”? With the answer variants: "yes" "no”.

The null bypothesis (HO): both variants of the answer are equally preferred by the respondents.

Alternative bypothesis (H1): one variant of the answer is preferred by the subjects participating in the study.

2. „Currently, would you be willing to do voluntary activities”? With the answers: ,yes”, „no”, „N.A.”.

The null bypothesis (HO): all variants of the answer are equally preferred by the surveyed subjects.

Alternative bypothesis (H1): one variant of the answer is mostly selected by the subjects participating in the study [78: 192].

To test the main assumption, we used the IBM SPSS Statistics (Cronk, 2012; Friese, 2014) and AtlasTi applications (Friese, 2014; Ferreira et all, 2016), for deepening the interpretation.

Thus, out of the 30 micro-community members, 25 participated in the past in volunteering, in circumstances which requested their presence (Table no. 4). It is to be noted that women's involvement in volunteering (17 subjects) is much higher than men's (8 subjects), probably because, as we shall see below, women believe that any activity they perform voluntarily for the people around them is volunteering. 
Table no. 4: Voluntary * Gender Crosstabulation

\begin{tabular}{|l|l|c|c|c|}
\hline \multirow{2}{*}{ Count } & \multicolumn{2}{|c|}{ Gender } & \multirow{2}{*}{ Total } \\
\cline { 3 - 4 } & Mo & 2 & Female & \\
\hline \multirow{2}{*}{ Voluntary } & No & 3 & 5 \\
& Yes & 8 & 17 & 25 \\
\hline Total & 10 & 20 & 30 \\
\hline
\end{tabular}

Source: data processing, by the authors, in SPSS

Regarding the respondents' availability to get involved in volunteering in a predictable time horizon (Table no. 5), most of them (25 subjects, representing $83.3 \%$ of the total participants in the study) answered affirmatively, two subjects responded negatively and 3 of them preferred not to answer that question.

Table no. 5: Volunteering Availability

\begin{tabular}{|c|c|c|c|c|c|}
\hline \multicolumn{2}{|c|}{} & Frequency & Percent & Valid Percent & Cumulative Percent \\
\hline \multirow{4}{*}{ Valid } & No & 2 & 6.7 & 6.7 & 6.7 \\
\cline { 2 - 6 } & Yes & 25 & 83.3 & 83.3 & 90.0 \\
\cline { 2 - 6 } & N.A. & 3 & 10.0 & 10.0 & 100.0 \\
\cline { 2 - 6 } & Total & 30 & 100.0 & 100.0 & \\
\hline
\end{tabular}

Source: data processing, by the authors, in SPSS

Our integration in the community life allowed us to better know the subjects surveyed, their daily concerns and, in particular, many common daily activities (from cooking and childcare to leisure). Thus, during the course of the research, by careful observation of the interaction among the subjects, a legitimate question appeared: "Ts the notion of volunteering known'? In order to elucidate this dilemma, we introduced the following question in the questionnaire: „Have you ever been the beneficiary of volunteering”? with the following answer variants: ,yes”, „no”, „do not know”.

Table no. 6: Gender * Volunteering Beneficiary Crosstabulation

\begin{tabular}{|c|c|c|c|c|c|}
\hline \multirow{2}{*}{\multicolumn{2}{|c|}{ Count }} & \multicolumn{3}{|c|}{ VBeneficiary } & \multirow{2}{*}{ Total } \\
\hline & & Yes & $\mathrm{No}$ & Don't know & \\
\hline \multirow{2}{*}{ Gender } & Male & 6 & 2 & 2 & 10 \\
\hline & Female & 10 & 5 & 5 & 20 \\
\hline \multicolumn{2}{|c|}{ Total } & 16 & 7 & 7 & 30 \\
\hline
\end{tabular}

Source: data processing, by the authors, in SPSS

The answers that we received to this question (Table no. 6), in conjunction with the answers to the questions that we used in the qualitative analysis, confirmed to us that, at the time of the survey, the notion of volunteering was somewhat unclear for some people in the micro-community. Thus, seven people argued convincingly that they had not benefited from the results of volunteering, while 7 other people said they didn't know about this fact. The paradox of the negative responses is that every day each of these people voluntarily performs at least one activity / task for the benefit of microcommunity (ex: distribution of teaching materials, transport of colleagues who could not 
move, supervision of the children in the group, etc.), being concomitantly volunteers and beneficiaries of volunteering.

The time allocated by each of the subjects to volunteering has a wide range of representations, as shown in Figure no. 2: from occasional activities (12 subjects) to total involvement in such activities ( 3 subjects); 2 of the respondents preferred not to answer the question.

The results presented up to this point of the quantitative analysis (rates of positive responses), confirm that the participants in the survey explicitly expressed their availability to involve in volunteering, so we will reject the null hypothesis in both cases (participation in the past and participation in volunteering in a predictable future,).

Our curiosity did not stop here and we wanted to find out what determines the surveyed subjects to involve in volunteering, so we designed the secondary objectives of the research, namely:

1. What is the context in which the subjects participating in the study were involved in volunteering;

2. Which are the conditions for the respondents to became involved in volunteering;

3. What are the consequences / outcomes of the respondents' involvement in volunteering.

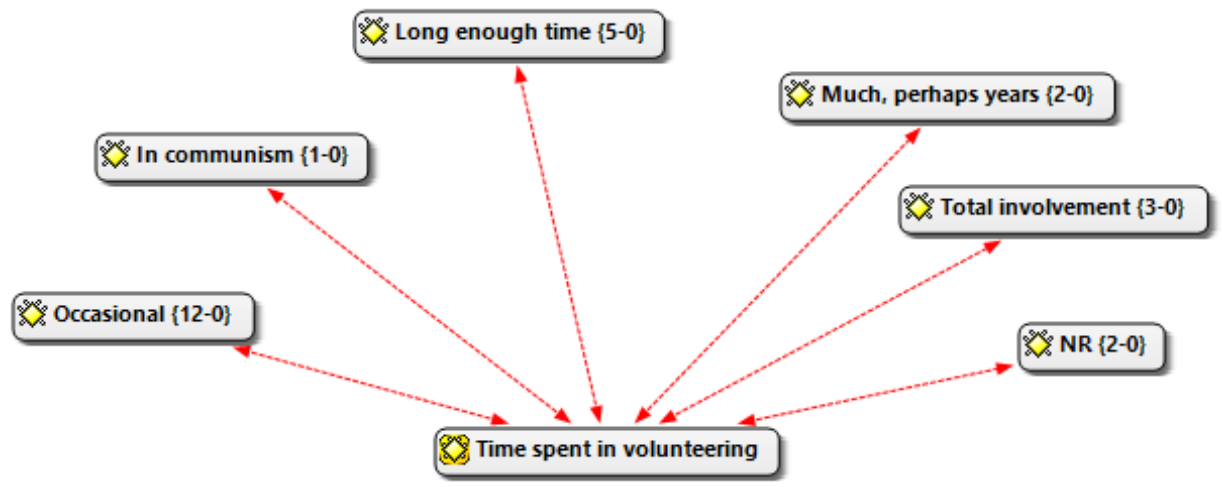

Figure no. 2: Time allotted to volunteering

Source: data processing, by the authors, in Atlas.Ti - response to the question: „How long did you spend volunteering?"

In order to clarify the three secondary objectives, we used the AtlasTi application to analyse the responses to the following questions (which we correlated, where necessary, with the results obtained in the quantitative analysis Section, with the observations, field notes and recordings that we have made):

1. What is the greatest satisfaction that you obtained from participating in voluntary activities?

2. Currently, would you be willing to volunteer? With answers: "yes", "no", "N.A.". Can you justify your response?

3. Can you tell us the most beautiful story of the achievements obtained through your work?

For the qualitative data processing we used the following: theoretical coding, qualitative content analysis, sequential analysis and visual presentation of the data. 
Table no. 7: Code Manager [HU: Volunteering]

\begin{tabular}{|l|c|l|l|}
\hline Name & Grounded & Code Families \\
\hline Causal Condition - volunteer & 17 & 01 Causal Conditions - volunteer \\
\hline Attitudinal value & 18 & 02 Volunteer motivations \\
\hline Creative value & 2 & 02 Volunteer motivations \\
\hline Experiential value & 5 & 02 Volunteer motivations \\
\hline Benefits for individuals & 4 & 03 Volunteering benefits \\
\hline Benefits for the community & 15 & 03 Volunteering benefits \\
\hline Benefits for the voluntary & 3 & 03 Volunteering benefits \\
\hline & 01 Family & 02 Family & 03 Family \\
\hline Causal Conditions & 17 & 6 & \\
\hline Attitudinal value & & 18 & \\
\hline Creative value & & 2 & 4 \\
\hline Experiential value & & & 3 \\
\hline Benefits for the community & & & \\
\hline Benefits for individuals & & & \\
\hline Benefits for the voluntary & & & \\
\hline
\end{tabular}

Source: Processing by the authors of the responses to the survey, using the AtlasTi application

Through the theoretical coding (open coding technique) we segmented the text, according to the algorithm in Figure no. 1, in three families of thematic codes that correspond to the secondary objectives of the research, as follows (Table no. 7):

- Code 01 - Causal conditions for volunteering, for which we have identified 17 quotes;

- Code 02 - Motivations of volunteers, comprising three distinct codes, as follows:

- Attitudinal Value, for which we identified 18 quotes. Six of these quotes simultaneously meet the criterion of causal condition;

- Creative value, for which we identified 2 quotes;

- Experiential value, for which 5 quotes were identified;

- Code 03 - Benefits of Volunteering, which contains 3 distinct codes, as follows:

- Benefits for the individual, for which we have identified 4 quotes;

- Benefits for the community, for which we have identified 15 quotes;

- Benefits for the volunteer, for which we have identified 3 quotes.

By structuring the material in this manner we could understand the reality with its lights and shadows, as depicted by the survey participants and, simultaneously, to capture the motivations of the volunteers, as well as the intimate mechanisms which ensure the cohesion of a community.

The responses recorded reveal the areas in which the survey participants conducted volunteer activities. Thus, we distinguish categories of beneficiaries of volunteer work such as (we use Italics to indicate the responses received, as they were coded in the text): - Education, the motivation being as simple as it is palpable in terms of its final result: 2:56 I I helped a child to learn a foreign language, to go to a foreign country and be with his mother again.] or 2:52 [The joy of those who receive. As a teacher, you have the satisfaction that the students, even those with disciplinary and learning problems, welcome you with love and you're glad that they see you, some even become passionate about the subject you are teaching (biology) and put into application specific models which you used]; 
- Health: 2:45 [What I liked most was when the kids stopped crying, got well and were happy to go bome with Mommy];

- Personal assistance: 2:54 [Having worked for almost 4 years with a lady who only now has started to feel the physical, mental and emotional effects. That person was unable to organize her daily activities especially those related to her own person - and when we met, willy - nilly she entered the working atmosphere.] 2:34 [Help for seniors without families. Physical recovery and leisure activities].

- Environmental services, a field where we have identified a variety of activities, starting from the simplest ones, such as cleaning the public spaces and creating new green spaces: 2:41 [I made flower gardens and useful plants (fruit trees, vineyard, vegetables); I raised houses], or,

2:50 [From my point of view, the only personal story in any volunteering which has always been manifested, was the joy and smiles in the people's eyes when we planted trees and picked up trash, we also smiled; when I visited children or elderly people who were less happy, we received and mixed together the smile and the tear], by engaging in research: 2:49 [In 2010, I managed to promote and exhibit a Romanian prototype of an invention in the field of air decontamination that received the gold medal at the International Salon of Inventions in Geneva].

- Most volunteer activities were identified in the social, self-awareness, social assistance and community cohesion sectors, of which the following drew our attention:

2:39 In 2008-2009 I found a book written in English and I started to translate it, without the guarantee that it will be published by a Romanian printing house. After, secular fights”, the book was published by Herald Printing House in 2012. It's the book entitled "That taboo against knowing who you are" by Alan $W$ atts], or

2:14 [It's easier to work in a community - the work ends faster. I can do for others what they cannot do and others can do for me what I cannot do], or

2:8 [If it is better for the community, it will be better for me too!], a statement that makes us think of a possible paradigm shift meant to put community development in the spotlight, or

2:57 [Focusing exclusively on the study object and participating to improve an aspect of society]. The examples may continue, since this presentation is by no means exhaustive.

Next, we will follow the working algorithm which corresponds to the secondary objectives of the study. Slightly confused by the negative answers received from some surveyed subjects regarding their lack of involvement in volunteering activities, we wanted to find out their motivation. Thus, we discovered that: "Other people's callousness and indifference and the non-involvement of the law” or, „To carry out volunteering you need first to make sure you have the means to support yourself. You can't be a volunteer and starve. Abroad, volunteers are those who have an income from pensions, etc.", or

"I live in a community who is not aware of this", are very good reasons for these surveyed subjects not to get involved in volunteering.

The causal conditions that lead the subjects to involve in volunteering (through social economy organizations, or individually) are related to both personal factors and objective reasons, imposed by society, generated by the existence of needs which are not covered by the public or private sectors, or by the need for community cohesion. When referring to life attitudes that lead the surveyed subjects to involve in volunteering, we can quote responses such as:

2: 3 [I want to forget about the murderous logic of profit at all cost and demonstrate that there are other possibilities];

2:17 [The need to give back from what I have received]; 
2:32 [When the direction and nature of volunteering converge with my motivations, I may work to help other people] or,

2:71 [The joy of helping when my support is required].

The causal conditions imposed by society refer to issues such as: 2:23 [There are needs that are not covered by the current private, commercial or public activities], or 2:63 [Need] or constraints related to a bygone era, 2:62 [In communism, we paid the debts to the International Monetary Fund].

The need to live in a cohesive community is covered by answers such as: 2:8 If it is better for the community, it will be better for me too!],

2:12 [Better living conditions for my family in that community (cleaning, better training of its members)],

2:66 [By working for others, I actually work for myself],

2:67 [Community cohesion],

2:70 [Offering additional help to the community].

In parallel, we identified a number of conditions related to a state of well-being of the volunteer:

2:61 [I like to belp people.]; 2:64 [In my job it is important to belp people]; 2:65 [Moral and professional satisfaction]; 2:68 [The beneficiaries were satisfied with the services supplied]; 2:69 [Contributing to achieving something good in any field, this is what makes me feel good].

The motivations leading to the involvement of the surveyed subjects in volunteering are related to the manifestation of the sense of solidarity, the need for social involvement, the need to be useful and, last but not least, personal fulfilment.

The result of volunteering is quantified through the created values, of which we identified three deeply human categories, as described by Victor Frankl in his book "Man's search for meaning": attitudinal values, through the attitude that we can adopt in spite of adversity or of an impossible to change suffering, resorting to the power of the spirit, able to transform suffering into a personal achievement; creative values, achieving something concrete by yourself; experiential values, obtained by living an experience (of good, beauty, truth, etc.) or through love.

Most of the identified values obtained by codification are the attitudinal ones, which represent a distinctive feature of the researched micro-community.

Some of these have especially drawn our attention: 2:3 [I want to forget about the murderous logic of profit at all cost and to demonstrate that there are other possibilities]; 2:24 [I feel good when I help other people. In general, the aid I have given returned to me exactly when I most needed it]; 2:53 [You work in a team without waiting for benefits. That's relaxing]; 2:17 [The need to give back from what I've got]; 2:25 [The joy of helping when my support is required].

Three of the responses fall into the creative values category:

2:2 [I haven't hidden any information related to the production process. I participated actively and I indirectly applied methods to improve the quality of the products that were manufactured in my department,

2:10 [Necessity],

2:51 [What would be a beautiful story about thinking?].

The experiential values identified in the recorded responses can be attributed to the interhuman relationships created during the volunteering:

2:26 [I like to belp people];

2:27 [Love for work and for other people];

2:28 [The joy of helping one's fellows]; 
2:35 [Contribution, usefulness, sense].

The results of the volunteer activity are converted into benefits for the individual beneficiary of volunteering, such as: 2:37 [Over the years, the respective person fondly remembers the good that - he or she - received],

Benefits for the community: 2:58 [I helped organize and develop an art project for high school students in Bucharest. This project was designed as a theatre, music and dance competition among artistic teams from different high schools. Most of the participating high schools were from Bucharest. I had a great satisfaction to see hundreds of children taking part in this project and feeling great, developing their creative and artistic abilities at the same time],

2:70 [I contributed to the implementation of programmes from which people with certain needs had to gain. Offering additional help to the community] and,

Benefits for the volunteers: 2:40 [I was integrated in a group]; 2:46 [Participation in the "Work and Travel in the USA" programme], to which a series of personal satisfactions are added, highlighted by the text encoding, as shown in Figure no. 3.

\section{Conclusions}

The social economy enterprise is an economic actor operating in a free market, in an increasingly aggressive competitive environment, without benefiting from facilities designed to help it achieve its social goals. Within this context, the in-depth understanding of the phenomenon represented by involving individuals in volunteering can be an extremely valuable piece of information for the managers of these entities when it comes to taking the adequate strategic decisions for this type of organisations, so as to obtain a competitive advantage that can be materialized in:

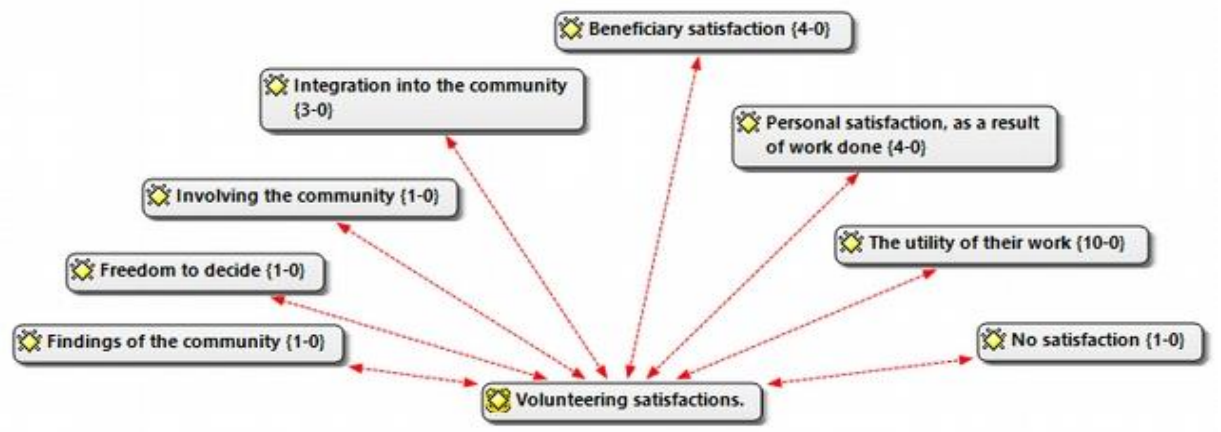

Figure no. 3: Satisfactions obtained by the participants in the study, in their role as volunteers

Source: data processing, by the authors, in AtlasTi

solutions / customer loyalty programmes; good relationships with the suppliers, staff motivation, using and motivating volunteers; prestige; recognition; etc.

From this perspective, the results of the study confirm that the members of micro-communities are active participants in community life, assume social responsibilities by participating in volunteering for the benefit of individuals or of the community, contributing to the creation of tangible economic, social and moral values for the community.

The detailed analysis which was carried out using qualitative research methods provides 
us with new, valuable information about the causal conditions which determine the participants in the study to involve in volunteering activities, their motivations and expectations, as well as the categories of benefits resulting from the deployment of voluntary activities.

Our direct involvement in the micro-community life allowed us to diversify the research instruments, by adding some additional ones such as: direct observation, informal dialogue, field notes, audio and video recordings, that have helped us shape an objective view regarding the surveyed subjects, thus completing the (sometimes laconic) responses received.

In another train of thoughts, the permanent interaction with the members of the microcommunity allowed us to test the questionnaire we used in the research and to add new, relevant questions to the field of study, which allowed us to find out how the relationship between the individual and the community was perceived.

Simultaneously, we have diversified the distribution channels of the questionnaire, the updated variant being available online at http://www.goo.gl/forms/Br3jBnNxVh. The information we collect using this instrument allows us to perform a nuanced, in-depth interpretation of the research topic - Improving the management of social economy enterprises, an essential factor for the development of local communities - which will provide us with a better understanding of the management methods known and used by the managers of social economy enterprises, the benefits of volunteering, how the individual - community relationship is perceived, to name just a few.

The effects that volunteering has on economic life cannot be ignored. Thus, a study that was conducted in Canada regarding the participation of immigrants in volunteering shows that about 200,000 full time jobs were offered to the people who were involved in volunteering, or that in a year they did more than 357 million hours of volunteer work the equivalent of the lifespan of approximately 600 people with an average life expectancy of 60 years (Ashton et all, 2003).

\section{References}

Allen, J., 2016, From Poverty to Power. CreateSpace Independent Publishing Platform. ISBN: 978-1535-44-0363, Available online: https://www.amazon.com/Poverty-Power-James-Allen/dp/15354403 68, (accessed on 19 November 2017).

Aron, A.; Aron, E.N.; Coups, E., 2014, Statistics for Psychology, 6th Edition, 2014, London: Pearson, pp. 305-348 Ashton, S.; Baker, N.; Parandeh, A., 2003, Building caring communities: The contributions of immigrant volunteers. A qualitative study into the experiences of immigrant volunteers at mainstream agencies. 2003, Coquitlam, BC, Canada: Community Volunteer Connections. Available online: http://www. volunteerconnections.net/buildingCaringCommunities.pdf, (accessed on 9 July 2017).

Ball, A., 2016, Social Enterprise Governance. Journal of Business Law. University of Pennsylvania. 2016, 18/(4): 926-929, Available online: http://scholarship.law.upenn.edu/jbl/voll8/iss4/1, (accessed on 20 November 2017).

Baltag, D.; Moraru, E., 2011, Responsibility and judicial accountability - guarantee for the individual freedom. University Juridical Studies Journal, 2011, IV/(1-2): 71, Available online: http://ulim.md/digilib/assets/files/Reviste\%202/revista drept 2011.pdf, (accessed on 9 July 2017).

Barkin, D.; Lemus, B., 2014, Rethinking the Social and Solidarity Society in Light of Community Practice. Sustainability. 2014. 6: 6432-6445; 
Battilana, J.; Lee, M., 2014, Advancing Research on Hybrid Organizing-Insight from the Study of Social Enterprises. The Academy of Management Annals. 2014, 8/(1): 397-441, Available online: http://dx.doi.org/10.1080/19416520.2014.893615, (accessed on 19 November 2017).

Bell, J.; Masaoka, J.; Zimmerman, S., 2010, Nonprofit Sustainability: Making Strategic Decisions for Financial Viability. 2010. New York: Jossey-Bass;

Bennis, W.G., 1969, Post-bureaucratic leadership. Society. 1969, 6/(9): 44-47, Available online: https://doi.org/10.1007/BF02819884, (accessed on 20 November 2017).

Bocanaila, T., 2014, Considerations on Law no. 78/2014 on regulation of volunteering, Acta Universitatis Danubius. Juridica, 2014, 10/(2), Available online: https://www.ceeol.com/search/articledetail?id $=279790$ (accessed on 15 November 2017).

Borzaga, C.; Bodini, R.,2014, What to Make of Social Innovation? Towards a Framework for Policy Development. Social Policy and Society. 2014. 13/(3)1., Available online: https://doi.org/10.1017/S1474746414000116, (accessed on 15 November 2017).

Brothers, J.; Sherman, A., 2011, Building nonprofit capacity: a guide to managing change through organizational lifecycles. 2011. New York: Jossey-Bass

Brown, W., 2017, Classification of program activities: how nonprofits create social value. Administrative Sciences. 2017. 7/(2): 1-7;

Bugg-Levine, A.; Kogut, B.; Kulatilaka, N.,2012, A new approach to funding social enterprises. Harvard Business Review. 2012. 90/(1). Available online: https://hbr.org/2012/01/a-new-approach-tofunding-social-enterprises, (accessed on 17 November 2017).

Burke, J.; Onwuegbuzie, A.; Turner, L., 2007, Toward a Definition of Mixed Methods Research. Journal of Mixed Methods Research (JMMR), 2007, 1/(2)

Castles, F.G., 2002, The future of the welfare state: crisis myths and crisis realities. International Journal of Health Services. 2002. 32/(2):255-277

Choi, N.; Majumdar, S., 2015, Social Innovation: Towards a Conceptualisation. Technology and Innovation for Social Change. 2015. 1: 7-34

Christie, M.J.; Honig, B., 2006, Social Entrepreneurship: new research findings. Journal of World Business. 2006. 41/(1): 1-5 (accessed on 14 November 2017).

Clocotici, V.; Stan, A., 2014, Applied Statistics in Psychology. Iasi: Polirom, pp.191-193, (in Romanian)

Cordery, C.; Sinclair, R., 2013, Measuring performance in the third sector. Qualitative research in Accounting \& Management, 2013, 10/(3/4): 196-212, Available online: https://doi.org/10.1108/QRAM-03-20130014, (accessed on 22 November 2017).

Cronk, B., 2012, How to Use SPSS Statistics: A Step-By-Step Guide to Analysis and Interpretation, $7^{\text {th }}$ Edition, 2012, London: Routledge

David, M.; Sutton, C., 2011, Social Research - An Introduction - 2nd Edition. 2011. London: Sage.

Durkheim, E., 2013, The Division of Labour in Society. New York: Free Press Publishing, 2014.

Epstein, M.; McFarlan, F., 2011, Measuring the Efficiency and Effectiveness of a Nonprofit's Performance, Strategic Finance, 2011. 93/(4): 27, Available online: https://www.researchgate.net/publication/ 285762164_Measuring_the_efficiency_and_effectiveness_of_a_nonprofit $\% 27$ s_performance, (accessed on 15 November 2017).

European Commission, 2013, Social Economy and Social Entrepreneurship, Social Europe Guide, 2013, 4: 7-9, EC Catalog N. : KE-BC-12-002-EN-C

European Commission, 2010, Study of volunteering in the European Union. Romania: Country Report 2010. G.H.K., Available online: http://www.ec.europa.eu/citizenship/pdf/national report ro en.pdf, (accessed on 20 November 2017).

Ferge, Z., 1997, The Changed Welfare Paradigm: The Individualization of The Social. Social \& Policy Administration. 1997. 33/(1): 20-44;

Ferreira, J.J.; Moreno, M.; Brandao, R.; Cerqueira, R., 2016, Multimedia in Cognitive- Intensive Practices: a case with ATLAS.ti supporting HCI Qualitative Research. 2016. San Jose - IEEE, Available online: http://ieeexplore.ieee/document/782 3711/, (accessed on 14 November 2017).

Frankl, V., 2006, “Man's search for meaning". Boston: Beacon Press, 2006;

Franz, H.-W.; Hochgerner, J.; Howaldt, J., 2010, Challenge Social Innovation: An Introduction. Springer, Berlin, Heidelberg. 2010. Available online: https://doi.org/10.1007/978 -3-642-32879-4 1, (accessed on 16 November 2017).

Friese, S., 2014, Qualitative Data Analysis with ATLAS.ti - 2nd Edition. 2014. London: London. 
Hancock, A.-M., 2012, Solidarity Politics for Millennials: A Guide to Ending the Oppression Olympics. 2012: xi-xii. Palgrave.

Harding, R., 2004, Social Enterprise: The New Economic Engine? Business Strategy Review. 2004. 15/(4): 3943;

Harrisson, D.; Széll, G.; Bourque, R., 2009, Social Innovation, the Social Economy and World Economic Development. Labour, Education \& Society. 2009. 17: 7-15, Peter Lang GmbH, Frankfurt am Main;

Haslam, A.; McGarty, C., 2014, Research Methods and Statistics in Psychology, 2nd Edition, 2014, London: Sage Foundation of Psychology Series, pp.240-243;

Hemerijck, A., 2012, When changing welfare states and the Eurocrisis meet. Sociologica, 2012, 1: 1-49, Available online: http://www.sociologica.mulino.it/doi/10. 2383/36887, (accessed on 14 November 2017).

Hope, T et al. Ubi Comp 2006: Ubiquitous Computing, 8th International Conference, Ubi Comp 2006, Orange County, CA, USA, September 2006 Proceedings, LNCS 4206, Dourish, P. \& Friday, A., Eds., Springer, p.389

Kenneth, A., 2005, Exploration in Classical Sociological Theory. Seeing the Social World. Thousand Oaks: Pine forge Press, 2005, pp. xi-xiii.

Klein, R., 2003, Why we need a new welfare state. Journal of Social Policy. 2003. 32: 290- 292.

Laskowski, W.; Loidl, R., 2012, Professionalization strategies of social work in social enterprises based on socio-economic ratios. ACRN Journal of Entrepreneurship Perspectives. 2012. 1/(1): 111-136, Available online: https://www.researchgate.net/publication/251238606, (accessed on 19 November 2017).

Laville, J.; Nyssens, M., 2004, Towards a theoretical socio-economic Approach, in Borzaga, C.; Defourny, J. The Social Enterprise - C.18: London-New York, Routledge, 2004, pp. 312-332

Lewis, M.; Swinney, D., 2007, Social Economy? Solidarity Economy? Exploring the Implications of Conceptual Nuance for Acting in a Volatile World. BC-Alberta Social Economy Research Alliance (BALTA). 2007. Available online: http://base.socioeco.org/docs/f3-lewis swinney.pdf, (accessed on 23 July 2017).

London, L.; Himonga, C.; Fick, N.; Stuttaford, M., 2015, Social solidarity and the right to health: essential elements for people-centred health systems. Health Policy and Planning, 2015, 30/(7): 938-945, Available online: https://doi.org/10.1093/heapol/czu083, (accessed on 9 October 2017).

Lund, M., 2013, Cooperative Equity and Ownership: An Introduction. University of Wisconsin Center for Cooperatives, 2013. Available online: http://www.uwcc.wisc.edu/pdf/Cooperative\%20Equity\% 20and\%20Ownership.pdf, (accessed on 20 November 2017).

Magzan, M., 2014, Social Economy: Inclusion of Preson and Human Sociability. Journal of Engineering Management and Competitiveness. 2014. 4/(1): 13-20;

McBride, D., 2017, The Process of Statistical Analysis in Psychology, 2017, London: Sage Publications, Inc., pp.171174

McCold, P; Wachtel, B., 1997, “Community Is Not a Place: A New Look at Community Justice Initiatives”, Available online: https://www.iirp.edu/eforum-archive/community-is-not-a-place-a-new-look-at-community-justiceinitiatives, (accessed on 23 June 2018)

Megan, P.; Rochelle, S.; Brueckner, M., 2017, Volunteering as a Subject of Research. Third Sector Review, 2017, 23/(1): 1-8, Available online: hhtp://www.search.informit.com.au/document Summary; $\mathrm{dn}=812582320330037$; res=IELAPA, (accessed on 22 November 2017).

Merriam-Webster Dictionary, 2017, Available online: https://www.merriam- webster.com/dictionary/ microcommunity, (accessed on 19 July 2018)

Milbourne, L.; Cushman, M., 2012, From the third sector to the big society: how changing UK Government policies have eroded third sector trust. Voluntas: international journal of voluntary and nonprofit organisations, 2012;

Moreau, C.; Mertens, S., 2013, Manager's competences in social enterprises: which specificities? Social Enterprise Journal. 2013, 9/(2): 164-183, Available online: https://doi.org/10. 1108/SEJ-01-20130005, (accessed on 19 November 2017).

Morgan, G.A.; Leech, N.L.; Gloeckner, G.; Barrett, K., 2012, IBM SPSS for Introductory Statistics: Use and Interpretation, $5^{\text {th }}$ Edition, 2012, London: Routledge.

Moscovici, S.; Buschini, F., 2007, Methodology of Social Sciences, Iasi: Polirom;

Moulaert, F.; Ailenei, O., 2005, Social Economy, Third Sector and Solidarity Relations: A Conceptual Synthesis from History to Present. Urban Studies. 2005. 42/(11): 2037- 2053 
Nakano, L., 2000, Volunteering as a lifestyle choice: negotiating self-identities in Japan. Ethnology, 2000, 39/(2): 93-107

Neamtan, N., 2009, Social Economy: Concepts and Challenges. Universities Forum. 2009. 1/(3): 1-5, Available online: http://www.universitasforum.org/index.php/ojs/article/view/31, (accessed on 14 November 2017).

Nogueira-Martins, M.; Bersusa, A.; Siqueira, S., 2010, Humanization and volunteering: a qualitative study in public hospitals. Revista de Saúde Pública. 2010, 44/(5): 942-949. Available online: http://www.dx.doi.org/10.1590/S0034-89102010005000032, (accessed on 8 August 2017).

Pantea, M.C., 2017, Understanding non-participation: perceived barriers in cross-border volunteering among Romanian youth. International Journal of Adolescence and Youth. 2015, 20/(3): 271-283, Available online: http://dx.doi.org/10.1080/02673843.2013.793205, (accessed on 9 July 2017).

Patton, M. Q., 2001, Qualitative Research \& Evaluation Methods, 3rd Edition, 2001, London: Sage Publications, Inc., pp. 339-380;

Padurean, T.M., 2013, The issue of solidarity. An interdisciplinary approach. PhD. Thesis, 2013, Cluj Napoca: Babes-Bolyai University Publishing. Available online: http://doctorat.ubbcluj.ro/ro/sustinerile publice_ale_tezelor_de_doctorat $/ ?$ an $=2013 \&$ facultatea $=15 \&$ domeniu $=19$, (accessed on 9 July 2017).

Petrella, F., 2014, Social entrepreneur; social entrepreneurship and social enterprise: semantic and controversies. Journal of Innovation Economics \& Management. 2014. 14/(2): 143-156

Phills, J.; Deiglmeier, K.; Miller, D., 2008, Rediscovering social innovation. Stanford Social Innovation Review, 2008, 1: 34-43, Available online: https://www.ssireview.org/articles/ rediscovering social innovation, (accessed on 14 November 2017).

Plerhoples, A., 2015, Social enterprise as commitment: a roadmap. Washington University Journal of Law \& Policy. 2015, 48/(10): 89-92, Available online: https://openscholarship.wustl. edu/law_journal_law_policy/vol48/iss1/10, (accessed on 20 November 2017).

Popescu, D.; State, C.; Nicolae, V.; Pavel, I., 2016, Empirical Research of the Knowledge Degree of Social Economy Enterprises in Stable Micro-communities. European Journal of Sustainable Development. 2016. 5/(4): 94-106;

Ramadan, M.A.; Borgonovi, E., 2015, Performance Measurement and Management in NonGovernmental Organizations. IOSR Journal of Business and Management. 2015. 17/(2): 70-76;

Restakis, J., 2006, Defining Social Economy: The BC Context. Vancouver. British Columbia Co-operative Association, 2006. Available online: https://www.msvu.ca/socialeconomyatlantic/pdfs/Defining SocialEconomy FnlJan1906.pdf, (accessed on 16 November 2017).

Rey-Garcia, M.; Liket, K.; Alvarez-Gonzales, L.; Maas, K., 2017, Back to Basics: Revisiting the relevance of beneficiaries for evaluation and accountability in nonprofits. Nonprofit Management and Leadership. 27/(4)-Summer: 493-511, (C) 2017 Wiley Periodicals, Inc.

Romanian Law No. 78/2014 on the regulation of voluntary work in Romania, Art. 3 (g): 2. Official Monitor of Romania No. 469/26 June 2014

Romanian Law No. 219/2015 on social economy, Art. 4 (a-c). Official Monitor of Romania No. 561 /28 July 2015

Rothstein, B. , 2001, The universal welfare state as a social dilemma. Rationality and Society. 2001. 13/(2): 213233, Available online: https://doi.org/10.1177/104346301013002004, (accessed on 15 November 2017).

Sablonnière, R.; Bourgeois, L.F.; Najih, M., 2013, Dramatic Social Change: A Psychological Perspective. Journal of Social and Political Psychology. 2013. 1/(1): 253-272;

Scârneci, F., 2006, Handbook of qualitative research in social and buman sciences, 2006, Braşov: "Transilvania" University Publishing, p.283;

Schmid, G., 2006, Social risk management through transitional labour markets. Socioeconomic Review, 2006, 4/(1): 1-33, Available online: https://doi.org/10.1093/SER/mwj029, (accessed on 14 November 2017).

Taylor, R.(Ed.), 2010, Third Sector Research. Springer, 2010;

Taylor-Goby, P., 2005, New Risks, New Welfare: The Transformation of the European Welfare State. Oxford Scholarship Online. 2005. Available online: http://www.oxfordscholarship.com/view/10.1093 /019926726X.001.0001/acprof-9780199267262-chapter-9 (accessed on 15 November 2017). 
Tibando, A.J., 2017, Understanding the difference and building a social business model that serves both. Medium Corporation, July, 17th 2017, Available online: https://medium.com/sojo-stories, (accessed on 17 November 2017).

Tihon, A.; Ingham, M., 2011, The Societal System and the Responsible Innovations: Freeing Sustainable Development from a Deadlock. Journal of Innovation Economics \& Management. 2011, 2/(8): 11-31;

Veenhoven, R., 2010, Life is getting better: societal evolution and fit with human nature. Social Indicators Research Journal. 2010, 97/(1): 105;

Voicu, B., 2010, Values and the sociology of values, pp.30-31, apud Vlasceanu, L. in Sociology, Polirom Publishing, Iasi, 2010, pp.249-294 (in Romanian).

Volkmann, Ch.; Tokarski, K.O.; Ernst,K., 2012, Social Entrepreneurship and Social Business. An Introduction and Discussion with Case Studies. 2012. Wuppertal, DE: Springer.

Wood, C.; Leighton, D., 2010, Measuring social value. The gap between policy and practice. Undercurrent Journal. 2010. 2: 7-9, Available online: http://search.informit.com.au/documentSummary;dn= 608274328337959; res=IELHSS, (accessed on 16 November 2017).

Yunus, M.; Moingeon, B.; Lehmann-Ortega, L., 2010, Building Social Business Models: Lessons from the Grameen Experience. Long Range Planning. 2010. 43/(2-3): 308-325, ISSN: 0024-6301, DOI: 10. 1016/j.lrp.2009.12.005 